\title{
Tomasz Tomczak
}

Uniwersytet Opolski

tomasz.tomczak@uni.opole.pl

ORCID: https://orcid.org/0000-0002-8499-4553

\section{Czy wniesienie powództwa oczywiście bezzasadnego $\mathrm{w}$ rozumieniu art. $191^{1}$ k.p.c. przerywa bieg przedawnienia?}

http://dx.doi.org/10.12775.SIT.2021.039

\section{Wprowadzenie}

Prawodawca Ustawą z dnia 4 lipca 2019 r. o zmianie ustawy Kodeks postępowania cywilnego oraz niektórych innych ustaw ${ }^{1}$ (dalej: nowelizacja) wprowadził do polskiej procedury cywilnej m.in. instytucję oddalenia powództwa jako oczywiście bezzasadnego (art. $191^{1}$ Ustawy z dnia 17 listopada 1964 r. - Kodeks postępowania cywilnego, dalej: k.p.c. ${ }^{2}$ ). Celem niniejszego artykułu nie jest jej kompleksowe omówienie ${ }^{3}$, a jedynie podjęcie próby odpowiedzi

\footnotetext{
${ }^{1}$ Dz.U. poz. 1469 ze zm.

2 Tekst jednolity: Dz.U. z 2020 r. poz. 1575.

${ }^{3} \mathrm{~W}$ odniesieniu do tej instytucji zob. przykładowo: Ł. Błaszczak, Powództwo oczywiście bezzasadne. Art. 191(1) k.p.c., Warszawa 2021; M. Manowska, w: Kodeks postępowania cywilnego. Komentarz, t. 1: Art. 1-477(16), red. A. Adamczuk, P. Pruś, M. Radwan, M. Sieńko, E. Stefańska, M. Manowska, Warszawa 2021, komentarz do art. 191'ㄹ O.M. Piaskowska, w: Kodeks postępowania cywilnego. Postępowanie procesowe. Komentarz aktualizowany, red. M. Kuchnio, A. Majchrowska, K. Panfil, J. Parafianowicz, A. Partyk, A. Rutkow-
} 
na pytanie: czy wniesienie powództwa oczywiście bezzasadnego $\mathrm{w}$ rozumieniu art. $191^{1}$ k.p.c. przerywa bieg przedawnienia?

Zgodnie $\mathrm{z}$ art. $191^{1} \S 3 \mathrm{w} \mathrm{zw} . \mathrm{z}$ art. $191^{1} \S 1$ k.p.c. sąd może oddalić powództwo na posiedzeniu niejawnym ${ }^{4}$, nie doręczając pozwu osobie wskazanej jako pozwany ani nie rozpoznając wniosków złożonych wraz $z$ pozwem, jeżeli $z$ treści pozwu i załączników oraz okoliczności dotyczących sprawy, a także faktów znanych powszechnie lub urzędowo (art. 228 k.p.c.) wynika oczywista bezzasadność powództwa.

W uzasadnieniu nowelizacji możemy przeczytać, że „szkodliwość dla wymiaru sprawiedliwości pozwu oczywiście bezzasadnego wynika przede wszystkim stąd, że procedowanie $z$ nim pochłania czas i pracę potrzebną na prowadzenie czynności w sprawach wytoczonych rzetelnie" . Główny cel wprowadzenia tej instytucji jest zatem jasny: szybsze rozstrzyganie przez sąd spraw, które nie zasługują na szersze procedowanie ${ }^{6}$. Tym samym wprowadzenie art. $191^{1}$ k.p.c. powinno $z$ założenia odciążyć nieco sądy cywilne i generalnie wpłynąć na szybsze rozstrzyganie przez nie spraw ${ }^{7}$. Można postawić tezę, że prawodawca chciał ukształtować instytucję powództwa oczywiście bezzasadnego jako „miecz jednosieczny” przeciwko nierzetelnym powodom.

ska, D. Rutkowski, A. Turczyn, O.M. Piaskowska, Gdańsk 2020, komentarz do art. $191^{1}$; Ł. Błaszczak, w: Kodeks postępowania cywilnego. Koszty sadowe $w$ sprawach cywilnych. Dochodzenie roszczeń $w$ postępowaniu grupowym. Przepisy przejściowe. Komentarz do zmian, t. 1 i 2, red. T. Zembrzuski, Warszawa 2020, komentarz do art. 191(1); E. Gapska, Przeciwdziałanie nadużyciom prawa procesowego $w$ znowelizowanym Kodeksie postępowania cywilnego. Cz. II: Powództwo oczywiście bezzasadne, „Monitor Prawniczy” 2019, nr 16, s. 865-873; T. Tomczak, Okoliczności dotyczace sprawy $w$ rozumieniu art. $191^{1}$ k.p.c. (powództwo oczywiście bezzasadne), „Monitor Prawniczy” 2021, nr 16.

${ }^{4}$ M. Manowska, wbrew literalnemu brzmieniu przepisu, zaznacza, że oddalenie powództwa musi nastąpić na posiedzeniu niejawnym. Zob. M. Manowska, Kodeks postępowania, komentarz do art. $191^{1}$ pkt 8.

${ }^{5}$ Druk sejmowy nr 3137, Sejm RP VIII kadencji, s. 36.

6 Zob. A. Kościołek, w: Kodeks postępowania cywilnego. Komentarz do ustawy z 4.7.2019 r. o zmianie ustawy - Kodeks postępowania cywilnego oraz niektórych innych ustaw, red. J. Gołaczyński, D. Szostek, Warszawa 2019, komentarz do art. $191^{1}$ k.p.c. pkt 3.

7 Zob. ibidem. 
Gdybyśmy jednak przyjęli, że oczywiście bezzasadne powództwo przerywa bieg przedawnienia, można by się zastanawiać, czy w okolicznościach stosunkowo łatwych do wykreowania przez powoda ustawodawca nie uczynił $z$ tej instytucji „miecza obosiecznego", który może być wykorzystany do darmowego przerywania terminu przedawnienia. Chodziłoby o sytuację, w której powód, w postępowaniu gospodarczym, wnosiłby powództwo i jeszcze przed doręczeniem pozwu pozwanemu dokonywałby przelewu dochodzonej wierzytelności na inny podmiot, a sąd, ze względu na brak legitymacji procesowej czynnej, oddalałby powództwo jako oczywiście bezzasadne ${ }^{8}$. Ze względu na m.in. zmiany podmiotowe raczej wykluczone będzie w tym przypadku mówienie o powadze rzeczy osądzonej w stosunku do nabywcy wierzytelności ${ }^{9}$. Przyjęcie w opisanej sytuacji, że wniesienie powództwa przerwało bieg

8 Szerzej na ten temat: T. Tomczak, Instytucja oddalenia powództwa oczywiście bezzasadnego jako stworzony przez ustawodawcę potencjalny mechanizm do darmowego przerywania biegu przedawnienia?, maszynopis w posiadaniu Autora (na etapie recenzji zewnętrznej w Przeglądzie Ustawodawstwa Gospodarczego).

9 Zgodnie $z$ art. 366 k.p.c. wyrok prawomocny ma powagę rzeczy osądzonej tylko co do tego, co w związku z podstawą sporu stanowiło przedmiot rozstrzygnięcia, a ponadto tylko między tymi samymi stronami. W piśmiennictwie i judykaturze zaznacza się, że pojęcie stron odnosi się również do następców prawnych, tj. np. nabywców przedmiotu sporu. Tak np. A. Jakubecki, w: Kodeks postępowania cywilnego. Komentarz, t. 1: Artykuły 1-366, red. T. Wiśniewski, Warszawa 2021, komentarz do art. 366 pkt 24; oraz postanowienie SN z dnia 2 kwietnia 2009 r., IV CSK 477/08, Lex nr 610220. W omawianych okolicznościach faktycznych należy jednak zaznaczyć, że powództwo jako oczywiście bezzasadne zostałoby oddalone w stosunku do pierwotnego powoda ze względu na brak legitymacji czynnej, a zmiana podmiotowa, ze względu na ograniczenia występujące w postępowaniu gospodarczym, nie byłaby możliwa. Tym samym wydaje się, że nie sposób w tym przypadku mówić o powadze rzeczy osądzonej czy rozszerzonej prawomocności w stosunku do nabywcy wierzytelności. Można się też zastanawiać, czy w takim razie nie mówilibyśmy o causa superveniens (zob. A. Partyk, w: Kodeks postępowania cywilnego. Postępowanie procesowe. Komentarz aktualizowany, red. O.M. Piaskowska, Warszawa 2021, Lex, komentarz do art. 366 pkt 14-17). Zagadnienie to z pewnością zasługuje na szersze rozważania, które wykraczają poza ramy niniejszego artykułu, gdyż w tym opracowaniu nacisk został położony na kwestie natury materialnoprawnej, a nie procesowej. W odniesieniu do zagadnień procesowych zob. T. Tomczak, Instytucja oddalenia powództwa. 
przedawnienia, mogłoby w istocie prowadzić do dodatkowego obciążenia sądów cywilnych zamiast ich odciążenia ${ }^{10}$. Celem niniejszego artykułu jest wykazanie, że wniesienie powództwa oczywiście bezzasadnego nie powinno być traktowane jako przerywające bieg przedawnienia.

\section{Podstawowe założenia}

Zanim autor niniejszego artykułu przejdzie do istoty rozważań, należałoby zwrócić uwagę na kilka raczej niekontrowersyjnych tez.

Po pierwsze, oczywista bezzasadność powództwa zachodzi wówczas, gdy każdy prawnik z góry, bez głębszej analizy prawnej stanu faktycznego, może powiedzieć, że powództwo nie może być uwzględnione ${ }^{11}$. Jako przykład takiego powództwa w doktrynie podaje się sytuację braku legitymacji czynnej procesowej ${ }^{12}$.

Po drugie, zgodnie $\mathrm{z}$ art. $123 \S 1$ pkt 1 k.c. ${ }^{13}$ bieg przedawnienia przerywa się m.in. przez każdą czynność przed sądem przedsięwziętą bezpośrednio w celu dochodzenia lub ustalenia albo zaspokojenia lub zabezpieczenia roszczenia. Za czynność przerywającą bieg przedawnienia uznaje się m.in. „wytoczenie powództwa

10 Więcej na ten temat poniżej.

11 Tak: postanowienie SN z dnia 8 października 1984 r., II CZ 112/84, Lex nr 8631. W czasach, gdy orzeczenie to było wydawane, art. $191^{1}$ k.p.c. jeszcze nie istniał, a orzeczenie zostało wydane w kontekście art. 116 § 2 k.p.c., który obecnie jest uchylony. W ten sam jednak sposób oczywistą bezzasadność powództwa obecnie w doktrynie definiuje: T. Szanciło, w: Kodeks postępowania cywilnego, t. 1: Komentarz. Art. 1-505 ${ }^{39}$, red. T. Szanciło, Warszawa 2019, komentarz do art. $191^{1}$ pkt 2. Pojęcie oczywistej bezzasadności powództwa jest sporne w piśmiennictwie, ale spotkało się z szerokim omówieniem, tym samym celem niniejszego artykułu nie jest dokładne rozważenie zakresu tego terminu.

12 Zob. T. Szanciło, Kodeks postępowania, komentarz do art. $191^{1}$ pkt 2. Przez legitymację procesową rozumie się „uprawnienie wypływające $z$ prawa materialnego (konkretnego stosunku prawnego) do występowania $z$ roszczeniem przeciwko innemu podmiotowi”. Tak: H. Pietrzkowski, Metodyka pracy sędziego $w$ sprawach cywilnych, Warszawa 2009, s. 126.

13 Ustawa $z$ dnia 23 kwietnia 1964 r. - Kodeks cywilny, tekst jednolity: Dz.U. z 2020 r. poz. 1740. 
o świadczenie będące przedmiotem roszczenia" ${ }^{14}$. Do rzeczonego przerwania dochodzi już w dniu wniesienia pozwu ${ }^{15}$.

\section{Darmowe przerwanie biegu przedawnienia roszczenia?}

Wyżej zaprezentowane tezy raczej nie budzą wątpliwości i są powszechnie akceptowane w doktrynie. Godząc się ze stanowiskiem, że wniesienie powództwa oczywiście bezzasadnego prowadzi do przerwania biegu przedawnienia roszczenia, warto zwrócić uwagę, że dochodziłoby do tego w sposób „darmowy”. Powództwo nie musiałoby być nawet opłacone. Zgodnie $z$ art. $191^{1} \S 2$ k.p.c., gdyby czynności, które ustawa nakazuje podjąć w następstwie wniesienia pozwu, miały być oczywiście niecelowe, można by je pominąć, w szczególności można by nie wzywać powoda do uiszczenia opłaty. W świetle art. 14a Ustawy z dnia 28 lipca 2005 r. o kosztach sądowych w sprawach cywilnych (dalej: u.k.s.c.) ${ }^{16}$ można się zastanawiać, czy przewodniczący może w ogóle wezwać powoda, pod rygorem zwrócenia pisma, do opłacenia pozwu (art. 130 § 1 k.p.c. $)^{17}$. Zakładając jednak, że przewodniczący wezwał do uiszczenia odpowiedniej opłaty, należy uznać, że powód w takim przypadku powinien uiścić opłatę $\mathrm{w}$ odpowiednim terminie, aby uniknąć zwrotu pozwu. Nie sprawia to jednak, że zakładane przerwanie biegu przedawnienia przestaje być „darmowe”. Zgodnie $z$ wprowadzonym wraz $z$ nowelizacją art. 14a u.k.s.c. w sprawie, w której powództwo oddalono na podstawie art. $191^{1} \mathrm{k}$.p.c., powoda nie obciąża się kosztami sądowymi. Zgodnie $z$ brzmieniem przepisu

14 Tak: P. Machnikowski, w: Kodeks cywilny. Komentarz, red. E. Gniewek, P. Machnikowski, Warszawa 2018, s. 312.

15 Ibidem, s. 314.

16 Tekst jednolity: Dz.U. z 2020 r. poz. 755. Brzmienie tego artykułu przywołane jest poniżej.

$17 \mathrm{~W}$ przypadku reprezentacji powoda przez profesjonalnego pełnomocnika - czy może zwrócić pozew w trybie art. $130^{2} \S 1$ k.p.c. 
i jak podkreśla się w doktrynie, w tym przypadku nieobciążenie kosztami sądowymi jest obligatoryjne ${ }^{18}$.

\section{Wniesienie powództwa oczywiście bezzasadnego jako czynność nieprzedsięwzięta bezpośrednio w celu dochodzenia roszczenia}

Wydaje się, że celem wprowadzenia instytucji oddalenia powództwa jako oczywiście bezzasadnego nie było umożliwienie darmowego przerywania biegu przedawnienia. Zwłaszcza że, jak słusznie zauważył ustawodawca i jak możemy przeczytać w uzasadnieniu nowelizacji, postępowanie pojednawcze bywało często wszczynane nie w celu zawarcia ugody, lecz jedynie w celu przerwania biegu przedawnienia roszczenia ${ }^{19}$. Właśnie m.in. $z$ tego względu doszło do podwyższenia opłaty od wniosku o zawezwanie do próby ugodowej $^{20}$. Gdyby teza, że powództwo oczywiście bezzasadne we wskazanych okolicznościach może prowadzić do darmowego przerwania biegu przedawnienia, okazała się zasadna, można by się spodziewać fali oczywiście bezzasadnych powództw mających na celu jedynie przerwanie biegu przedawnienia.

Należałoby jednak poszukać argumentów przeciwko tezie o przerwaniu biegu przedawnienia przez wniesienie oczywiście bezzasadnego powództwa. Argumenty takie można znaleźć na gruncie prawa materialnego, tj. na gruncie art. 123 k.c. ${ }^{21}$ Zgodnie $z$ brzmieniem

18 Zob. P. Feliga, w: Ustawa o kosztach sadowych $w$ sprawach cywilnych. Komentarz, red. M. Uliasz, P. Feliga, Warszawa 2020, komentarz do art. 14(a) pkt 7.

19 Zob. druk sejmowy nr 3137, Sejm RP VIII kadencji, s. 170 uzasadnienia.

20 Przed 21 sierpnia 2019 r. opłata sądowa od wniosku o zawezwanie do próby ugodowej była stała i wynosiła $300 \mathrm{zł}$. Obecnie opłata ta wynosi piątą część opłaty od pozwu. Zob. poprzednie i obecne brzmienie art. 19 ust. 3 pkt 3 u.k.s.c. W uzasadnieniu nowelizacji możemy przeczytać: „Wydaje się, że ustalenie tej części na poziomie jednej piątej opłaty wystarczy do zapobieżenia nadużywaniu instytucji wniosku o zawezwanie do próby ugodowej, a jednocześnie nie uczyni postępowania pojednawczego nieosiągalnym dla stron”. Zob. druk sejmowy nr 3137, Sejm RP VIII kadencji, s. 197 uzasadnienia.

21 Jeżeli chodzi o argumenty na gruncie prawa procesowego, zob. T. Tomczak, Instytucja oddalenia powództwa. 
tego artykułu bieg przedawnienia przerywa się m.in. przez każdą czynność przed sądem przedsięwziętą bezpośrednio w celu dochodzenia roszczenia ${ }^{22}$. Powstaje zatem pytanie: czy wniesienie oczywiście bezzasadnego powództwa stanowi czynność przed sądem przedsięwziętą bezpośrednio w celu dochodzenia roszczenia?

Mogłoby się wydawać, że ciężko dyskutować z tezami, że wytoczenie powództwa o świadczenie będące przedmiotem roszczenia przerywa bieg przedawnienia oraz że do przerwania dochodzi $\mathrm{w}$ dniu wniesienia pozwu. W przypadku powództwa oczywiście bezzasadnego mamy jednak do czynienia $z$ sytuacją szczególną, tym samym, co najmniej, należałoby spróbować taką dyskusję podjąć.

W odniesieniu do drugiego i kolejnych wniosków o zawezwanie do próby ugodowej oraz przerywania przez nie biegu przedawnienia Sąd Najwyższy, stosunkowo niedawno, wydał trzy interesujące orzeczenia $^{23}$. W pierwszym $z$ tych orzeczeń SN postawił tezę, że zawezwanie do próby ugodowej jest czynnością przerywającą bieg przedawnienia, jeżeli stanowczo nie ustalono, że przedsięwzięto ją bezpośrednio w innym celu niż wskazany w art. $123 \S 1$ pkt 1 k.c. ${ }^{24}$ W drugim stwierdził, że kolejne zawezwanie do próby ugodowej jest taką czynnością, która może wywołać skutek przewidziany w art. $123 \S 1$ pkt 1 k.c., ale jedynie wówczas, gdy w okolicznościach stanu faktycznego zaistnieje podstawa do oceny, że czynność tę przedsięwzięto bezpośrednio w celu wskazanym w tym przepisie $^{25}$. W ostatnim orzeczeniu SN uznał, że nie może być sporu

22 Zob. art. 123 pkt 1 k.c. W doktrynie można spotkać stanowisko, że czynność procesowa jest podjęta bezpośrednio w celu dochodzenia „wówczas, gdy skutkiem tej czynności jest prowadzenie przez organ jakiegoś wyodrębnionego zespołu działań (postępowanie w szerokim znaczeniu), które mogą zakończyć się wydaniem orzeczenia zasądzającego (bądź zawarciem ugody sądowej) [...]”. Zob. P. Machnikowski, Kodeks cywilny, s. 312.

${ }^{23}$ Wyrok SN z dnia 28 stycznia 2016 r., III CSK 50/15, Lex nr 1975839; wyrok SN z dnia 19 lutego 2016 r., V CSK 365/15, Lex nr 2023441; wyrok SN z dnia 10 stycznia 2017 r., V CSK 204/16, Lex nr 2252331.

24 Zob. wyrok SN z dnia 28 stycznia 2016 r., III CSK 50/15, Lex nr 1975839.

25 Wyrok SN z dnia 19 lutego 2016 r., V CSK 365/15, Lex nr 2023441. 
co do tego, że nie jest czynnością zmierzającą bezpośrednio do dochodzenia roszczenia zawezwanie do próby ugodowej, którego celem jest jedynie wydłużenie okresu zaskarżalności wierzytelności przez doprowadzenie do kolejnej przerwy biegu przedawnienia ${ }^{26}$. Taki cel pozostaje zarówno w sprzeczności z założeniami instytucji przedawnienia roszczenia, którymi są przede wszystkim czasowe ograniczenie uprawnienia służącego wierzycielowi i przyznanie prawa do uchylenia się od zaspokojenia roszczenia zobowiązanemu, jak i w sprzeczności z podstawowym założeniem postępowania pojednawczego, którym jest doprowadzenie do zawarcia ugody, a nie do przerwy biegu przedawnienia ${ }^{27}$. W każdym jednak przypadku, niezależnie od tego, czy jest to pierwsze zawezwanie, czy kolejne, sąd jest zobowiązany do zbadania, czy zachodzą przesłanki określone w art. $123 \S 1$ pkt 1 k.c., a więc również - czy jest to czynność, która potencjalnie może doprowadzić do realizacji roszczenia, oraz jaki jest jej rzeczywisty cel ${ }^{28}$.

Innymi słowy, można powiedzieć, że Sąd Najwyższy ostatnio zaczął bliżej przyglądać się przesłance „bezpośredniości” występującej w art. $123 \S 1$ pkt 1 k.c. Postawione tezy, które zostały sformułowane w kontekście zawezwania do próby ugodowej, należy przenieść na grunt analizowanej sytuacji. $Z$ orzeczeń tych wynika, że sąd powinien zbadać, czy wniesienie powództwa może doprowadzić do realizacji roszczenia oraz jaki był jego rzeczywisty cel. Zakładając, że mamy do czynienia z powództwem oczywiście bezzasadnym, jego wniesienie nie jest w stanie doprowadzić do realizacji roszczenia. Należy przypomnieć, że oczywista bezzasadność zachodzi wówczas, gdy każdy prawnik bez głębszej analizy może powiedzieć, że powództwo nie może być uwzględnione. Skoro powództwo „oczywiście” nie może być uwzględnione, to takie powództwo nie może doprowadzić do realizacji roszczenia. Co więcej, nie można też wykluczyć przypadków, w których zbadanie, jaki był rzeczywisty cel wniesienia powództwa oczywiście bezzasadnego,

\footnotetext{
${ }^{26}$ Wyrok SN z dnia 10 stycznia 2017 r., V CSK 204/16, Lex nr 2252331.

27 Ibidem.

28 Ibidem.
} 
może doprowadzić do wniosku, że było nim po prostu przerwanie biegu przedawnienia.

Tym samym, choć teza ta może być kontrowersyjna, należy stwierdzić, że wniesienie powództwa oczywiście bezzasadnego $\mathrm{w}$ rozumieniu art. $191^{1}$ k.p.c. nie spowoduje przerwania biegu przedawnienia. Zwłaszcza w opisanej na wstępie sytuacji utraty legitymacji procesowej czynnej. Takiej czynności, w świetle całokształtu okoliczności, zwyczajnie nie będzie można uznać za przedsięwziętą bezpośrednio w celu dochodzenia lub zaspokojenia roszczenia w rozumieniu art. $123 \S 1$ pkt 1 k.c. $Z$ akademickiej uczciwości należy zaznaczyć kontrowersyjność postawionej tezy. Owa problematyczność wynika $z$ faktu, że odnosi się ona do czynności, jaką jest wniesienie powództwa, opiera się na orzecznictwie dotyczącym zawezwania do próby ugodowej, i to orzecznictwie, które dotyczyło nie pierwszego wniosku o zawezwanie do próby ugodowej, a drugiego i kolejnych.

\section{Podsumowanie i wnioski}

W niniejszym artykule zostało rozważone, czy wniesienie powództwa oczywiście bezzasadnego $\mathrm{w}$ rozumieniu art. $191^{1}$ k.p.c. przerywa bieg przedawnienia. Została postawiona teza, że takie powództwo nie spowoduje przerwania biegu przedawnienia ze względu na brak jego przedsięwzięcia bezpośrednio w celu dochodzenia lub zaspokojenia roszczenia w rozumieniu art. $123 \S 1$ pkt 1 k.c.

Nawet jeżeli założymy, że za pomocą przedstawionej argumentacji jesteśmy w stanie zniweczyć skutek w postaci darmowego przerwania biegu przedawnienia, niewątpliwie rozwiązanie to będzie wymagało stosunkowo kreatywnej interpretacji, tj. takiej, która obecnie odbiega od powszechnie akceptowanej tezy ${ }^{29}$. Może zatem do art. $191^{1}$ k.p.c. należałoby wprowadzić wyraźny przepis stanowiący, że powództwo, które zostało oddalone jako oczywiście bezzasadne, nie prowadzi do przerwania biegu przedawnienia?

29 Tj. tezy, że np. wniesienie powództwa o świadczenie będące przedmiotem roszczenia może nie prowadzić do przerwania biegu przedawnienia. 
Na koniec można zaznaczyć, że niniejszy artykuł ukazuje, do jakich skutków może prowadzić próba szybkiego znowelizowania przepisów, bez odpowiedniego, holistycznego podejścia. Prawodawca, chcąc wprowadzić instytucję przeciwko nierzetelnym powodom, stworzył narzędzie, które mogą oni próbować wykorzystać, aby przerywać bieg przedawnienia swoich roszczeń. Dodatkowo ta próba może ich nic nie kosztować, a jedynie obciążać sądy cywilne.

\section{STRESZCZENIE}

Czy wniesienie powództwa oczywiście bezzasadnego w rozumieniu art. $191^{1}$ k.p.c. przerywa bieg przedawnienia?

Prawodawca Ustawą z dnia 4 lipca 2019 r. o zmianie ustawy - Kodeks postępowania cywilnego oraz niektórych innych ustaw wprowadził do polskiej procedury cywilnej m.in. instytucję oddalenia powództwa jako oczywiście bezzasadnego (art. $191^{1}$ k.p.c.). Celem niniejszego artykułu jest podjęcie próby odpowiedzi na pytanie: czy wniesienie powództwa oczywiście bezzasadnego w rozumieniu art. $191^{1}$ k.p.c. przerywa bieg przedawnienia? Rozważania nad tym zagadnieniem prowadzą do wniosku, że odpowiedź na to pytanie powinna być negatywna.

Słowa kluczowe: powództwo oczywiście bezzasadne; przedawnienie

\section{SUMMARY}

Does bringing an action manifestly unfounded within the meaning of Article $191^{1}$ of the Code of Civil Procedure interrupt the limitation period?

By the Act of 4 July 2019 amending the Act - Code of Civil Procedure and certain other acts, the legislator introduced to the Polish civil procedure, inter alia, the institution of dismissal of the claim as manifestly unfounded (Article $191^{1}$ of the Polish Civil Procedure Code). The purpose of this paper is to try to answer the question: does the bringing of an action manifestly unfounded within the meaning of Article $191^{1}$ of the Code of Civil Proce- 
dure interrupt the limitation period? The considerations in the article lead to the conclusion that the answer to such a question shall be negative.

Keywords: manifestly unfounded action; limitation period

\section{BIBLIOGRAFIA}

Błaszczak Ł., w: Kodeks postępowania cywilnego. Koszty sqdowe w sprawach cywilnych. Dochodzenie roszczeń $w$ postępowaniu grupowym. Przepisy przejściowe. Komentarz do zmian, t. 1 i 2, red. T. Zembrzuski, Warszawa 2020.

Błaszczak Ł., Powództwo oczywiście bezzasadne. Art. 191(1) k.p.c., Warszawa 2021.

Feliga P., w: Ustawa o kosztach sadowych $w$ sprawach cywilnych. Komentarz, red. M. Uliasz, P. Feliga, Warszawa 2020.

Gapska E., Przeciwdziałanie nadużyciom prawa procesowego $w$ znowelizowanym Kodeksie postępowania cywilnego. Cz. II: Powództwo oczywiście bezzasadne, „Monitor Prawniczy” 2019, nr 16.

Jakubecki A., w: Kodeks postępowania cywilnego. Komentarz, t. 1: ArtykuŁy 1-366, red. T. Wiśniewski, Warszawa 2021.

Kościołek A., w: Kodeks postępowania cywilnego. Komentarz do ustawy z 4.7.2019 r. o zmianie ustawy - Kodeks postępowania cywilnego oraz niektórych innych ustaw, red. J. Gołaczyński, D. Szostek, Warszawa 2019.

Machnikowski P., w: Kodeks cywilny. Komentarz, red. E. Gniewek, P. Machnikowski, Warszawa 2018.

Manowska M. w: Kodeks postępowania cywilnego. Komentarz, t. 1: Art. 1-477(16), red. A. Adamczuk, P. Pruś, M. Radwan, M. Sieńko, E. Stefańska, M. Manowska, Warszawa 2021.

Partyk A., w: Kodeks postępowania cywilnego. Postępowanie procesowe. Komentarz aktualizowany, red. O.M. Piaskowska, Warszawa 2021, Lex.

Piaskowska O.M., w: Kodeks postępowania cywilnego. Postępowanie procesowe. Komentarz aktualizowany, red. M. Kuchnio, A. Majchrowska, K. Panfil, J. Parafianowicz, A. Partyk, A. Rutkowska, D. Rutkowski, A. Turczyn, O.M. Piaskowska, Gdańsk 2020.

Pietrzkowski H., Metodyka pracy sędziego w sprawach cywilnych, Warszawa 2009. 
$418 \mid$ Tomasz Tomczak

Szanciło T., w: Kodeks postępowania cywilnego, t. 1: Komentarz. Art. 1-505 ${ }^{39}$, red. T. Szanciło, Warszawa 2019.

Tomczak T., Instytucja oddalenia powództwa oczywiście bezzasadnego jako stworzony przez ustawodawcę potencjalny mechanizm do darmowego przerywania biegu przedawnienia?, maszynopis w posiadaniu Autora (na etapie recenzji zewnętrznej w Przeglądzie Ustawodawstwa Gospodarczego).

Tomczak T., Okoliczności dotyczace sprawy $w$ rozumieniu art. $191^{1}$ k.p.c. (powództwo oczywiście bezzasadne), „Monitor Prawniczy” 2021, nr 16. 